\title{
Differential Screening of a Human Chromosome 3 Library Identifies Hepatocyte Growth Factor-like/Macrophage-stimulating Protein and Its Receptor in Injured Lung
}

\author{
Possible Implications for Neuroendocrine Cell Survival
}

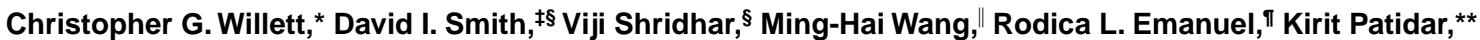
Sherry A. Graham, ${ }^{\star \star}$ Fan Zhang, ${ }^{\star \star}$ Victoria Hatch, $\$ \S$ David J. Sugarbaker, ${ }^{\ddagger \ddagger}$ and Mary E. Sunday ${ }^{\star \star}$

*Department of Radiation Oncology, Massachusetts General Hospital and Harvard Medical School, Boston, Massachusetts 02114;

${ }^{\ddagger}$ Department of Experimental Pathology, Mayo Foundation, Rochester, Minnesota 55905; ${ }^{\circledR}$ Department of Internal Medicine, Department

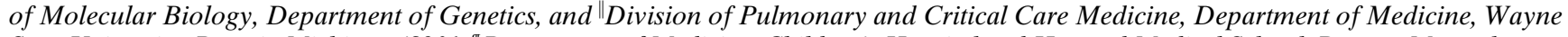
State University, Detroit, Michigan 48201; " Department of Medicine, Children's Hospital and Harvard Medical School, Boston, Massachusetts 02114; **Department of Pathology and ${ }^{\ddagger}$ Department of Surgery, Brigham and Women’s Hospital and Harvard Medical School, Boston, Massachusetts 02115; and ${ }^{\$}$ Department of Environmental Health, Harvard School of Public Health, Boston, Massachusetts 01125
\end{abstract}

\begin{abstract}
Transient pulmonary neuroendocrine cell hyperplasia and non-neuroendocrine lung tumors develop in nitrosaminetreated hamsters, which we hypothesized might modulate epithelial cell phenotype by expressing gene(s) homologous to human chromosome $3 p$ gene(s) deleted in small cell carcinoma of the lung (SCLC). We differentially screened a chromosome 3 library using nitrosamine-treated versus normal hamster lung cDNAs and identified hepatocyte growth factor-like/macrophage-stimulating protein (HGFL/MSP) in injured lung. HGFL/MSP mRNA is low to undetectable in human SCLC and carcinoid tumors, but the HGFL/MSP tyrosine kinase receptor, RON, is present and functional on many of these neuroendocrine tumors. In H835, a pulmonary carcinoid cell line, and H187, a SCLC cell line, HGFL/ MSP induced adhesion/flattening and apoptosis. Using viable cell counts to assess proliferation after $14 \mathrm{~d}$ of treatment with HGFL/MSP, there is growth inhibition of $\mathrm{H} 835$ but not H187. Nitrosamine-treated hamsters also demonstrate pulmonary neuroendocrine cell apoptosis in situ during the same time period as expression of the endogenous HGFL/ MSP gene, immediately preceding the spontaneous regression of neuroendocrine cell hyperplasia. These observations suggest that HGFL/MSP might regulate neuroendocrine cell survival during preneoplastic lung injury, which could influence the ultimate tumor cell phenotype. (J. Clin. Invest. 1997. 99:2979-2991.) Key words: tyrosine phosphorylation • apoptosis $\bullet$ cell adhesion $\bullet$ nitrosamines $\bullet$ cell proliferation
\end{abstract}

\section{Introduction}

Molecular genetic studies of small cell carcinoma of the lung $(\mathrm{SCLC})^{1}$ have shown that the loss or inactivation of two distinct tumor suppressor genes-the retinoblastoma gene $(\mathrm{Rb})$

\footnotetext{
Address correspondence to Dr. Mary E. Sunday, Brigham \& Women's Hospital, Department of Pathology, 75 Francis Street, Boston, MA 02115. Phone: 617-355-8402; FAX: 617-721-5654; E-mail: sunday@a1.tch.harvard.edu

Received for publication 4 October 1996 and accepted in revised form 19 March 1997.
}

The Journal of Clinical Investigation

Volume 99, Number 12, June 1997, 2979-2991 and p53 genes-plays critical roles in the development of this malignancy (1-4). It is generally recognized that solid tumors such as lung and colon cancers harbor multiple genetic abnormalities $(3,4)$. There is a minimum of three putative tumor suppressor genes which map to the short arm of chromosome 3 and the consistent loss of heterozygosity of chromosome $3 p$ sequences in SCLC suggests that one or more of these genes might play a role in SCLC development (5-13). With the exception of the successful cloning of the 3 p25 von HippelLindau disease gene (12), the definitive identification of the other $3 p$ suppressor genes has been elusive. A single mutation affecting von-Hippel-Lindau disease has been described in only 1 of 33 SCLC cell lines, but not in cell lines derived from 33 non-small cell lung carcinomas of the lung (NSCLCs) or 2 carcinoids (14). Abnormal FHIT transcripts occur in lung cancer (13), but their significance is not universally accepted, with some concerns that these might simply represent alternative splicing variants, or could reflect simply the plasticity of the cancer cell genome (15).

Human SCLC is generally believed to be derived from transformed pulmonary neuroendocrine (NE) cells (16), similar to pulmonary carcinoid tumors (17). Although there is no animal model of SCLC to aid in the elucidation of its biology, our laboratory has been investigating a hamster model of pulmonary NE hyperplasia induced by nitrosamines and $65 \%$ hyperoxia $\left(\mathrm{O}_{2}\right)(18-20)$. Our long-term objective was to define the relationship between pulmonary NE cell hyperplasia and neoplasia. Hamsters treated with diethylnitrosamine (DEN) with or without $\mathrm{O}_{2}$ for 3 mo develop pulmonary NE cell hyperplasia. DEN/O $\mathrm{O}_{2}$ induces $\mathrm{NE}$ cell hyperplasia about fivefold more intense than that observed in hamsters treated with DEN alone. In addition, immunostaining for proliferating cell nuclear antigen labels only rare NE cells, suggesting that this pulmonary NE cell hyperplasia predominantly represents cell differentiation and/or increased cell survival rather than simply NE cell proliferation (19). Similarly treated hamsters develop only non-NE lung tumors with a high rate of K-ras mutations after 10 mo (20-22), which are similar to human NSCLCs.

\footnotetext{
1. Abbreviations used in this paper: CGRP, calcitonin gene-related peptide; DAPI, 4',6-diamidino-2-phenylindole; DEN, diethylnitrosamine; ECL, enhanced chemiluminescence; EM, electron microscopy; HGFL, hepatocyte growth factor-like; MSP, macrophage-stimulating protein; NE, neuroendocrine; NSCLC, non-small cell carcinoma of the lung; RON, MSP tyrosine kinase receptor; RT, reverse transcription; SCLC, small cell carcinoma of the lung.
} 
One possible explanation for the lack of SCLC in rodents is that genes which downregulate numbers of differentiated $\mathrm{NE}$ cells might be induced during preneoplastic lung injury by nitrosamines. We hypothesized that human chromosome $3 p$ might harbor such putative inducible regulatory genes because SCLCs are generally NE in phenotype and consistently harbor homozygous deletions or loss of heterozygosity of chromosome $3 p$ sequences. To address this question, we differentially screened a human chromosome 3-specific genomic library using lung cDNAs from hamsters treated with nitrosamines versus normal adult hamsters. This study identifies the gene encoding hepatocyte growth factor-like/macrophage-stimulating protein (HGFL/MSP) at chromosome 3p21.3 as a candidate inducible regulatory gene. For simplicity, we will refer to HGFL/MSP as MSP for the remainder of the paper. The MSP tyrosine kinase receptor, $\mathrm{RON}$, has been shown recently to map also to 3p21.3 (23), and is known to be expressed in apparently normal human lung (23). MSP mRNA is low to undetectable in human SCLC and pulmonary carcinoid tumors, but RON is present and functional on many of these NE tumors. In two different NE carcinoma cell lines, MSP induces adhesion/flattening and apoptosis; at the same time, MSP treatment induces growth inhibition of a carcinoid cell line but not an SCLC cell line. These results indicate that MSP can regulate survival of NE cells in vitro, and suggest that similar regulatory mechanisms might occur in vivo. Finally, we demonstrate that apoptosis occurs in NE cells in DEN-treated hamster lung with a time course which parallels the endogenous expression of the MSP gene. Thus, NE cell apoptosis could explain the spontaneous downregulation of NE cell hyperplasia observed in nitrosamine-treated hamsters, and could be a factor leading to preferential development of non-NE lung tumors in rodents.

\section{Methods}

Care and treatment of hamsters. Outbred female Syrian golden hamsters (virus and pathogen-free) were purchased from Charles River Laboratories (Wilmington, MA) at $6 \mathrm{wk}$ of age and were maintained with or without $65 \% \mathrm{O}_{2}$ in compliance with Interdisciplinary Principles and Guidelines for the Use of Animals in Research, Testing, and Education, as described previously $(18,19)$. The animals were given DEN $(20 \mathrm{mg} / \mathrm{kg}$ in PBS) or PBS as detailed previously $(18,19)$. At harvest, animals were rapidly asphyxiated with carbon dioxide.

Library construction and differential screening. The cosmid library was prepared using genomic DNA from human chromosome 3-specific somatic cell hybrids with 5,500 individual colonies identified as containing human sequences $(<5 \%$ contamination with hamster sequences), as detailed previously (24). Total RNA was prepared from hamster lung tissues as detailed elsewhere (18). Lung tissues treated with DEN for $12 \mathrm{wk}$ were chosen for differential screening because peak pulmonary NE cell hyperplasia occurred at this time point, when a putative gene involved in regulating NE cell numbers might be expressed. ${ }^{32} \mathrm{P}$-labeled cDNAs were prepared from $1 \mu \mathrm{g}$ of total RNA using $50 \mu \mathrm{Ci}$ of $\left[{ }^{32} \mathrm{P}\right] \mathrm{dCTP}$, Moloney murine leukemia virus reverse transcriptase (2 U, Bethesda Research Laboratories, Gaithersburg, MD), RNAsin (5 U, No. R4380; Sigma Chemical Co., St. Louis, MO) and random hexamers (1 U, 5'-pd(N)6; Pharmacia LKB Biotechnology, Piscataway, NJ) in a total volume of $10 \mu \mathrm{l}$ of $50 \mathrm{mM}$ Tris- $\mathrm{HCl}(\mathrm{pH} 8.3), 75 \mathrm{mM} \mathrm{KCl}, 10 \mathrm{mM}$ DTT, and $3 \mathrm{mM}$ $\mathrm{MgCl}_{2}$ for $60 \mathrm{~min}$ at $42^{\circ} \mathrm{C}$. These cDNAs were used to screen duplicate nitrocellulose membrane filters bearing colony imprints from 96well plates for both primary and secondary screening. Tertiary screening was carried out using a hamster-specific repeat to exclude clones containing hamster sequences, which could be contaminants.
Chromosome mapping. Human chromosome 3-specific cosmids identified in our differential screen were mapped to specific subregions on chromosome 3 by identifying unique sequence hybridization probes from each cosmid and hybridizing these to a somatic cell hybrid deletion mapping panel as described previously (25).

$P C R$ on reverse-transcribed RNA for MSP, RON, and actin transcripts. cDNA was prepared and reverse transcription (RT) PCR reactions were carried out as described previously $(18,19)$, using 35 cycles of PCR for MSP and RON or 22 cycles for actin, each cycle including denaturation $\left(0.5 \mathrm{~min}, 93^{\circ} \mathrm{C}\right)$, annealing $\left(1.0 \mathrm{~min}, 50^{\circ} \mathrm{C}\right)$, and extension $\left(1-3 \mathrm{~min}, 72^{\circ} \mathrm{C}\right)$. Synthetic oligodeoxynucleotide pairs were designed to span at least one intron, corresponding to conserved sequences for murine beta-actin (yielding a 243-bp product) and human gamma-actin (yielding a 240-bp fragment), murine MSP (bp 782-1609, yielding an 827-bp insert, for hamster RNA analyses) (26), human MSP (bp 886-1555, yielding a 669-bp product, for human RNA analyses) (27), and human RON (bp 1642-2862, yielding an 1200-bp product) (23). Rodent RON sequence is not available, so the hamster RON RT-PCR was carried out using human primers. Southern blots of the PCR products were probed with the corresponding end-labeled internal oligonucleotide specific for MSP, RON, or actin. The sequences of the primers used are given as follows: Actin (murine): 5': GTGGGCCGCTCTAGGCACCA; 3': TGGCCTTAGGGTTCAGGGGG; Probe: AACTGGGACGACATGGAGAAGATCTGGCAC; Actin (human): 5': GTGGGGCGCCCCAGGCACCA; 3': TGGCCTTGGGGTTCAGGGGG; Probe: AACTGGGACGACATGGAGAAAATCTGGCAC; MSP (murine): 5': GCGAGAATTCTGTGACCTCCCC; 3': TCAGTACCCACTGCTCCTTCA; Probe: ATTCTGGACCCCCCAGAC; MSP (human): 5': AATACCACCACTGCGGGCGT; 3': TCAGTATCCACTGCTCCTTCA; Probe: TGTACAACGCCGGATCTGGTAGCA; RON (human): 5': CATGGCATTTCATGGGCTGT; 3': GGTGACCACTCTACCCAGgAtATGACA; and Probe: CTGGTCTGAGTTTTGAGGTG. For semiquantitative RT-PCR, conditions were determined such that the number of cycles was approximately one-third maximal and thus within the linear range of detection (see Fig. 1).

Human cell lines and tumor tissues. HepG2 human hepatocellular carcinoma cell line was used as a positive control for MSP. Human lung carcinoma cell lines were cultured as described previously (28): SCLCs: H60, H82, H146, H187, H209, and H249; carcinoids: H720, H835, and H679. Samples of primary SCLCs (verified by frozen section histopathology to be $>90 \%$ tumor cells) and adjacent non-neoplastic lung were obtained immediately after therapeutic surgical resection (lobectomy or pneumonectomy) and snap-frozen in liquid nitrogen before RNA preparation for RT-PCR analyses. These protocols were conducted according to strict institutional and NIH guidelines for use of human tissues which would otherwise be discarded.

Detection of RON receptor phosphorylation. Rabbit IgG antisynthetic COOH-terminal peptide (20mer) of RON beta-chain was generated by immunizing rabbits with RON peptide conjugated to keyhole limpet hemocyanin (29). Sources of monoclonal antiphosphotyrosine IgG (clone 4G10), goat anti-rabbit IgG conjugated with horseradish peroxidase, and enhanced chemiluminescence (ECL) detection reagents have been described previously. Four cell lines (H82, H187, H720, and H835) were used for phosphorylation assays. Detailed protocols have been described previously (29) (see Fig. 4 B). RON-transfected MDCK cells (clone RE7, $4 \times 10^{6}$ cells) were used as a positive control. After stimulation with MSP, cells were lysed, and proteins were precipitated with rabbit anti-RON peptide $\operatorname{IgG}$ and run on $8.0 \%$ SDS-PAGE gels under reduced conditions. Proteins were transferred to membranes which were incubated with antiphosphotyrosine (4G10) overnight, followed by horseradish peroxidaseconjugated goat anti-mouse IgG and ECL detection reagents.

Growth assays. Cell lines were treated with MSP (1, 3, and 10 $\mathrm{nM}$ ) for 5-14 d and viable cell counts determined in the presence of $0.5 \%$ trypan blue using a hemacytometer. For $\left[{ }^{3} \mathrm{H}\right]$ thymidine incorporation, cells were grown in 96-well plates at $10^{4}$ cells per well in a vol- 
ume of $200 \mu \mathrm{l}$ with or without MSP $(1,3$, and $10 \mathrm{nM})$ for $2-5 \mathrm{~d}$. For the last $4 \mathrm{~h}$ of culture, $1 \mu \mathrm{Ci}$ of $\left[{ }^{3} \mathrm{H}\right]$ thymidine was added per well. Cells were harvested on filter mats using a semiautomatic cell harvester (model 1004; Skatron, Inc., Sterling, VA). Four to eight replicates were used per group in each experiment. Filters were counted according to standard protocols.

Cell adhesion and scanning electron microscopy (EM). Phase-contrast microscopy and Polaroid photography were carried out using H835 carcinoid cells grown in $25 \mathrm{~cm}^{2}$ flasks. Nonadherent H835 cells grown in $25 \mathrm{~cm}^{2}$ flasks were harvested by one gentle wash with media to collect loose cells. $4 \mathrm{ml}$ of PBS was added per flask before mechanical disruption of the remainder of the cells. Viable cell counts were carried out using trypan blue exclusion as described above.

For scanning EM, H835 cells were grown on $0.4 \mu \mathrm{m}$ pore size cell culture inserts (Falcon 3095; Becton Dickinson, Franklin Lakes, NJ) in 24-well plates with media above and below. Scanning EM was carried out according to routine procedures using cells fixed overnight in $2.5 \%$ glutaraldehyde, $1 \%$ paraformaldehyde in PBS. Cells were dehydrated with a graded series of ethanol solutions, critical-point dried (in $\mathrm{CO}_{2}$ ), mounted, and coated with gold-palladium before examination by scanning EM.

Apoptosis assay. Flow cytometric and in situ analysis for DNA fragmentation was carried out using H835, H187, and H720 cells grown in the presence of MSP $(3 \mathrm{nM})$ or in media alone. Fluorescein isothiocyanate-digoxigenin nucleotide labeling of 3'-OH DNA ends was carried out on cell suspensions according to the manufacturer's specifications with 15 min of proteinase K treatment (ApopTag; Oncor, Inc., Gaithersburg, $\mathrm{MD}$ ), using 4',6-diamidino-2-phenylindole (DAPI) and/or propidium iodide as nuclear counterstains. Specimens were analyzed by flow cytometry at $530 \mathrm{~nm}$ (for fluorescein) and $620 \mathrm{~nm}$ (for propidium iodide, red). A portion of each specimen was spun onto a glass slide using a cytocentrifuge for viewing at 510-550 nm (green to yellow, fluorescein) and 360$370 \mathrm{~nm}$ (blue, DAPI). Some samples were used for preparation of DNA and agarose gel electrophoresis, as previously described (30).

In situ analysis for DNA fragmentation in tissue sections was carried out using the same ApopTag fluorescence protocol (see above) on hamster lung sections which had been immunostained previously for calcitonin gene-related peptide (CGRP) $(18,19)$. Sections were counterstained using DAPI to visualize nuclei in the sections. For this preliminary survey, analysis was restricted to qualitative assessment of ApopTag fluorescence and/or apoptotic bodies in CGRP-positive NE cells to determine the time frame during which NE cell apoptosis might occur in this lung injury model.

Statistical analyses. Numerical data were analyzed using the unpaired Student's $t$ test, with values expressed as mean \pm 1 SEM or 1 SD.

\section{Results}

Differential screening and genomic Southern blots. The differential screening of a human chromosome 3-specific cosmid library using hamster lung cDNAs from 12 -wk DEN/O ${ }_{2}$-treated animals versus normal adults yielded 186 primary colonies on duplicate 96-well plate filters. These 186 colonies were rescreened on a new set of duplicate filters, and 39 were confirmed as being differentially expressed. Screening of purified cosmid DNA was then carried out on slot blots to exclude hamster sequences. Seven uniquely human genes were identified, three of which mapped to $3 p$ (data not shown). Southern blotting of EcoRI digests of these seven cosmid DNAs was carried out to identify small $(\leq 1 \mathrm{~kb})$ fragments of each cosmid clone bearing cDNA sequence without repeats, for DNA sequencing, and for use as probes for mapping with a panel of chromosome 3 somatic cell hybrids (25). A 114-bp fragment of one of the clones (1697) was identified by DNA sequencing as highly homologous to the published nucleic acid and amino acid sequences of the human cDNA encoding HGFL from bp 984 to 1090 (31) (Table I).

HGFL is known to be identical to MSP $(27,32,33)$. Mapping using a panel of chromosome 3 somatic cell hybrids confirmed that clone 1697 mapped to 3p21-24. This agrees with previous studies which mapped the MSP gene to 3p21.3 (27, 31, 33). Genomic Southern blots from primary lung tumors (including both SCLCs and NSCLCs) and kidney tumors and the corresponding non-neoplastic lung or kidney were probed with clone 1697 . There were no gross deletions or abnormalities of any band from tumor tissues as compared to non-neoplastic tissue adjacent to the tumor.

Semiquantitative RT-PCR. RT-PCR conditions were established which allowed linear detection of MSP, its receptor, RON, and beta-actin. Increased RNA input from a positive control cell line (NSCLC H596) led to linear increases in RTPCR signal for MSP (referred to as 1697 in the figures because the amplified region is that segment of the MSP gene corresponding to clone 1697), its receptor, RON, and beta-actin, comparing different quantities (over a two log scale) of total RNA in the RT reaction (Fig. 1). These observations indicate a linear correlation between the relative amounts of given mRNAs

Table I. Sequence Comparisons Between Human HGFL/MSP and Clone 1697

(A) Nucleotide comparison between human HGFL/MSP and clone 1697 (85\% identity)

\begin{tabular}{|c|c|c|c|c|c|c|c|c|c|c|c|c|c|c|c|}
\hline HGFL. & 984 & G GAG & $\mathrm{AAC}$ & TTC & TGC & CGG & AAC & $\mathrm{CCC}$ & GAC & GGC & TCA & GAG & GCG & CCC & TGG \\
\hline 1697. & 11 & $G \ldots$ & $\ldots$ & $\ldots$ & $\ldots$ & G. . & C. G & . T. & AGA & $\ldots$ & G.A & CT. & $\ldots$ & $\ldots$ & \\
\hline HGFL. & 1027 & TGC & TTC & $\mathrm{ACA}$ & CTG & CGG & CCC & GGC & ATG & CGC & GCG & GCC & $\mathrm{TTT}$ & TGC & TAC \\
\hline 1697. & 54 & $\ldots$ & $\ldots$ & $\ldots$ & $\ldots$ & $\ldots$ & $\ldots$ &. $\mathrm{N}^{*}$ & $* *$ & A. G & $A G$. & $\ldots$ & $\cdots$ & & \\
\hline HGFL. & 1069 & CAG & ATC & CGG & CGT & TGT & $\mathrm{ACA}$ & GAC & G & & & & & & \\
\hline 1697. & 96 & $\ldots$ & $\ldots$ & $\ldots$ & $\ldots$ & $\ldots$ & $\ldots$ & C. . & . & & & & & & \\
\hline
\end{tabular}

(B) Amino acid comparison between human HGFL/MSP and clone 1697 (75\% identity, one of 8 amino acids conservatively substituted)

\begin{tabular}{|c|c|c|c|c|c|c|c|c|c|c|c|c|c|}
\hline HGFL. & Glu & Asn & Phe & Cys & Arg & Asn & Pro & Asp & Gly & Ser & Glu & Ala & Pro \\
\hline 1697. & & & & & Gly & Glu & His & Arg & . & Ala & Leu & & \\
\hline HGFL. & Cys & Phe & Thr & Leu & Arg & Pro & Gly & Met & Arg & Ala & Ala & Phe & Cys \\
\hline 1697. & 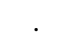 & $\cdot$ & $\cdot$ & 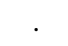 & $\cdot$ & . & $*$ & $*$ & . & Arg & . & . & . \\
\hline HGFL. & Gln & Ile & Arg & Arg & Cys & Thr & Asp & & & & & & \\
\hline 1697. & . & . & . & . & . & . & His & & & & & & \\
\hline
\end{tabular}

* indicates unknown sequence. 
1697 mRNA

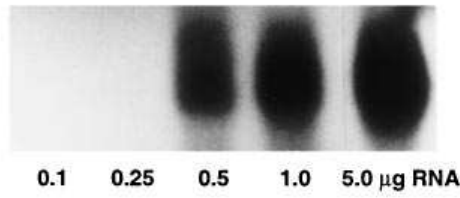

RON mRNA

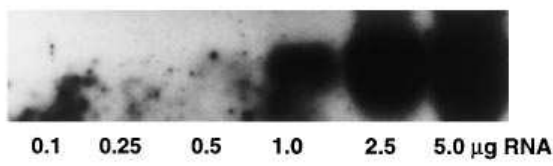

ACTIN MRNA

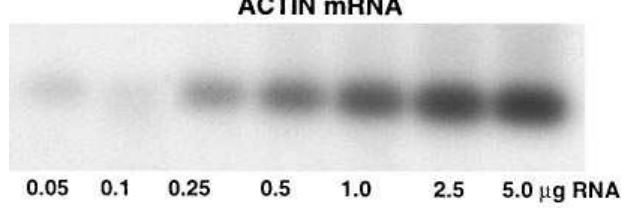

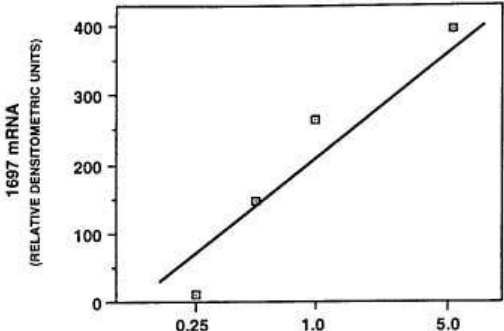
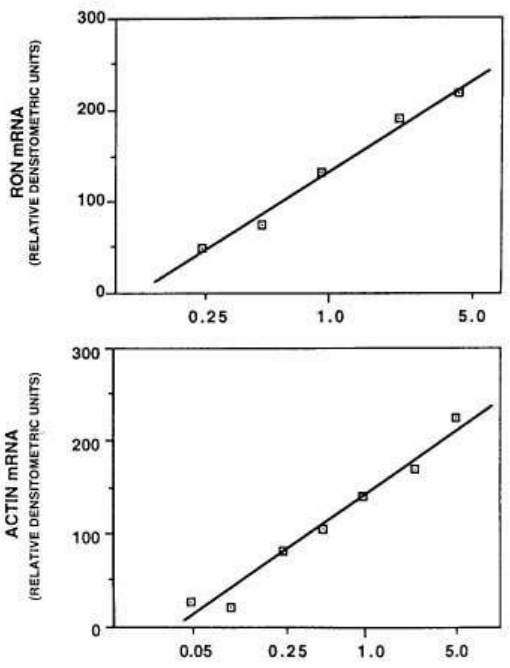

Mg TOTAL RNART REACTION
Figure 1. Semiquantitative RT-PCR analyses. RT-PCR was carried out from reverse-transcribed total RNA isolated from H596 lung carcinoma cells. PCR primers were designed to amplify the segment of the MSP gene coding region identified in clone 1697, a segment of the MSP receptor, RON, and betaactin as a housekeeping gene control. The figure shows autoradiograms of RT-PCR Southern blots probed with internal probes as detailed in Methods. 0.05-5 $\mu \mathrm{g}$ of total RNA was used per RT reaction, $1 \mu$ of which was used for PCR, illustrating the semiquantitative nature of this assay for MSP (referred to as 1697 because this represents amplification of the same region as the original human clone 1697), RON, and actin. The results of three-dimensional densitometric integration of the bands are plotted next to the autoradiograms as a function of micrograms of input RNA per RT reaction representing the averages of two separate determinations. present in the products of a given RT reaction. Thus, under the defined conditions, the relative band intensities for MSP and RON can be compared to actin as a control reference housekeeping mRNA in the same RT reaction tube.

Differential expression of the MSP gene in a hamster model of preneoplastic lung injury. To confirm that MSP is differentially expressed in lung tissues from hamsters treated with DEN, semiquantitative RT-PCR analyses were carried out using total lung RNA from hamsters treated for 2-20 wk with DEN with or without $\mathrm{O}_{2}$, versus age-matched controls given vehicle alone. The results of these RT-PCR analyses are shown in Fig. 2. The identity of the hamster MSP band (1697) detected on RT-PCR Southern blots is confirmed by nucleic acid sequencing, which reveals $91 \%$ amino acid identity compared to murine MSP (data not shown). It is apparent that MSP mRNA is strongly expressed as early as 2 wk after beginning treatment with DEN (two of three animals were positive after $2 \mathrm{wk}$, and all three animals were positive after 4 and 6 weeks). All animals were strongly positive after 9-12 wk of treatment. MSP mRNA levels thereafter dropped off, becoming undetectable in all animals by $20 \mathrm{wk}$ after the initiation of DEN treatment, by which time NE cell hyperplasia had spontaneously regressed in all of these animals. In contrast to animals treated with DEN alone, hamsters treated with $\mathrm{DEN} / \mathrm{O}_{2}$ developed profound pulmonary NE cell hyperplasia (18) which spontaneously regressed in about half of the animals $(18,19)$. In $\mathrm{DEN} / \mathrm{O}_{2}$-treated hamsters, there were lower levels of MSP gene expression in the lung, and MSP mRNAs were not detectable until after 9-16 wk of $\mathrm{DEN} / \mathrm{O}_{2}$ treatment (Fig. 2) (data not shown). In summary, the numbers of $\mathrm{DEN} / \mathrm{O}_{2}-$ treated hamsters expressing MSP mRNA in the lung are: one of three after $9 \mathrm{wk}$, three of four after $12 \mathrm{wk}$, neither of two af- ter $13 \mathrm{wk}$, one of two after $14 \mathrm{wk}$; and two of three after $16 \mathrm{wk}$ of $\mathrm{DEN} / \mathrm{O}_{2}$. MSP mRNA was undetectable in lung tissues from age-matched normal hamsters (Fig. 2). RON mRNA was also induced in hamsters treated with DEN (present in 17 of 17 animals after 2-16 wk of DEN, and 2 of 3 animals after $20 \mathrm{wk}$ of DEN) or DEN/O $/$ (present in 17 of 19 animals after 2-16 wk of $\mathrm{DEN} / \mathrm{O}_{2}$, and 1 of 3 animals after $20 \mathrm{wk}$ of treatment) but was undetectable in lung tissue from most normal adult hamsters (occurring at low levels in only 1 of 12 normal adult hamster controls, at age $20 \mathrm{wk}$, corresponding to $12 \mathrm{wk}$ of DEN treatment) (data not shown).

The only available MSP antisera, developed for Western analyses of human tissues (27), do not detect immunoreactive MSP in control sections of either fixed or frozen human or hamster liver, which is a strong positive control (34) (data not shown). In several experiments, the levels of MSP mRNAs in lung (positive by RT-PCR) were below the limit of detection by in situ hybridization even when homologous cRNA probes were used (data not shown). Hence, we turned to a panel of lung cancer cell lines to determine whether MSP is expressed in specific epithelial cell types, with our primary focus on $\mathrm{NE}$ cells. Separate analyses of MSP in NSCLCs, representing various non-NE cell types, are reported elsewhere (Willett, C.G., M.H. Wang, D.I. Smith, V. Shridhar, R. Emanuel, K. Patidar, S.A. Graham, F. Zhang, D.J. Sugarbaker, and M.E. Sunday, manuscript submitted for publication).

Expression of $m R N A$ encoding MSP in human SCLCs and carcinoid cell lines. To evaluate whether MSP gene expression occurs in NE subtypes of lung cancer, we screened a panel of tumor cell lines using RT-PCR. The results are given in Fig. 3. As a positive control, the HepG2 hepatocellular carcinoma cell line (Fig. 3, lane 1) was used, with the single band detected 


\section{Weeks of DEN}

1697

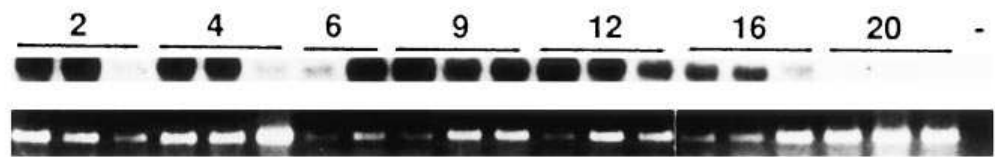

\section{Weeks of DEN/O2}

1697

$\frac{2}{4}-\frac{6}{9}-\frac{9}{9}-12{ }^{14} 16 \quad 20$

Actin

\section{Untreated Controls}

1697

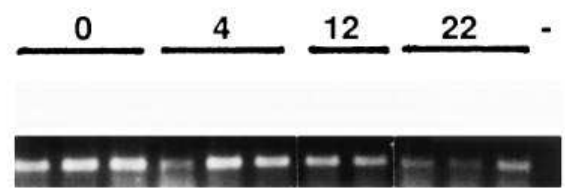

Figure 2. Differential expression of MSP (1697) in lung of nitrosaminetreated hamsters. Using semiquantitative RT-PCR, MSP mRNA was induced in hamster lung by $2-16$ wk of treatment with DEN (twice weekly injections as detailed in Methods). A second set of hamsters treated with DEN together with $65 \%$ hyperoxia $\left(\mathrm{DEN} / \mathrm{O}_{2}\right)$ had marked inhibition of MSP mRNA levels.

Each lane represents lung RNA from one hamster at the indicated time point (weeks). MSP mRNA was absent from normal age-matched adult hamster lung ( 0 wk of treatment corresponds to 8 wk of age). in human specimens occurring at $\sim 670 \mathrm{bp}$. There was no detectable expression in 18-wk gestation normal human fetal lung (Fig. 3, lane 2). Three of six SCLC cell lines tested (H60, H146, and H187) demonstrated low levels of MSP mRNA on long exposures of autoradiograms, but the PCR product in these SCLCs was slightly smaller in size than the liver homologue. MSP was undetectable in two carcinoid cell lines. All lanes demonstrated good actin control bands (the upper band which specifically hybridizes to an internal actin primer; the other, lower band appearing on ethidium gels is not reproducible and does not hybridize with an internal primer probe), except the no RT negative control.

Analysis of four primary SCLCs and the corresponding adjacent non-neoplastic lung demonstrated a total lack of MSP mRNA in all samples, in spite of excellent detection of MSP mRNA in positive controls and strong actin bands derived from all samples (data not shown).

Expression of $m R N A$ encoding $R O N$, the receptor protein tyrosine kinase for MSP in human NE tumor cell lines. Although MSP gene expression does not appear to be a promi- nent feature of NE lung tumors (SCLCs and carcinoids), it seemed reasonable that MSP could be acting as a paracrine regulatory factor for NE cells. To determine whether the receptor for MSP is transcribed in NE subtypes of lung cancer, we used RT-PCR to screen a panel of tumor cell lines similar to the panel used for Fig. 3. The results are given in Fig. 4 A. A single band was detected in these human specimens at $\sim 1200$ $\mathrm{bp}$, as expected. The strongest expression of the RON gene occured in cell lines derived from two of six SCLCs (H187 > H60) and two of four carcinoids (H835 and H679). Much lower levels of RON mRNA were also present in the SCLC line H249, most clearly evident on longer exposures of autoradiograms. All lanes showed good actin control bands, except the no RT negative controls (data not shown). RON mRNA was undetectable in all four primary SCLCs and adjacent nonneoplastic lung in spite of an excellent positive control in the same RT-PCR experiment (data not shown).

Tyrosine phosphorylation of RON in lung cancer cell lines. To determine whether RON gene expression is associated with specific cellular responses, we first carried out RON phos-

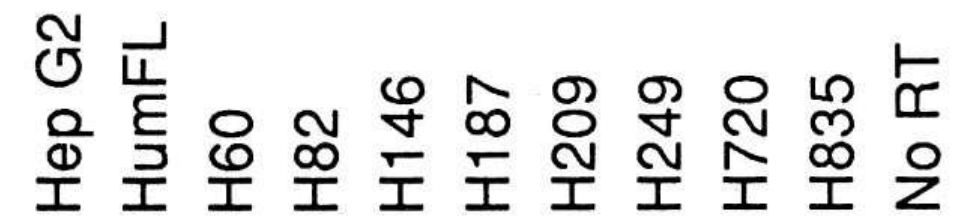

\section{7}
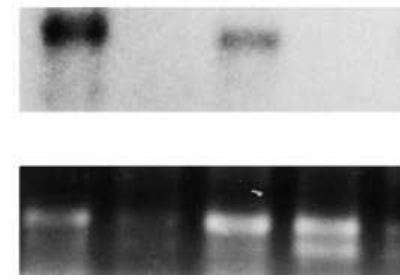

Figure 3. Analyses of MSP gene expression in human SCLC and carcinoid cell lines. The presence of MSP mRNA in human NE tumor cell lines was evaluated by RT-PCR. Top panel, from left to right: HepG2 (positive control, human hepatocellular carcinoma), 18-wk gestation human fetal lung, six SCLC cell lines (H60, H82, H146, H187, H209, and H249), and two carcinoid cell lines (H720, and H835), and no RT (negative control). 


\section{A RT-PCR}

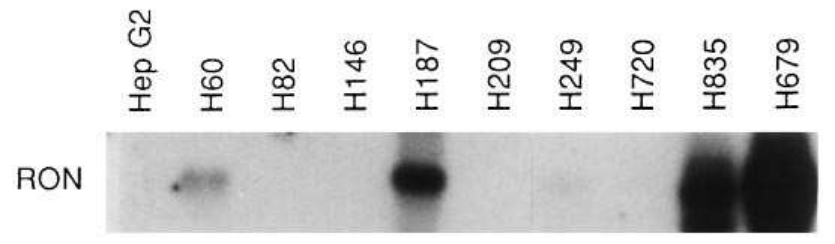

Actin

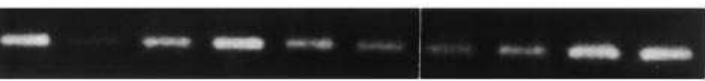

B RON Tyr Phosphorylation

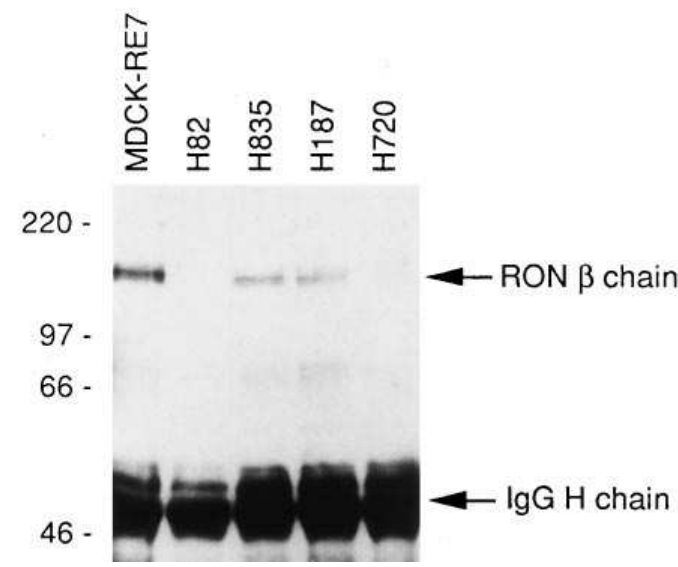

Figure 4. RON (MSP receptor) gene expression and tyrosine phosphorylation in human NE lung tumor cell lines. $(A)$ RON gene expression. The presence of RON (MSP receptor) mRNA in human tumor cell lines was evaluated by RT-PCR. Top panel, from left to right: HepG2, six SCLC cell lines (H60, H82, H146, H187, H209, and H249), and three carcinoid cell lines (H720, H835, and H679). (B) RON tyrosine phosphorylation. Cells at $1 \times 10^{7} / \mathrm{ml}$ were stimulated with $5 \mathrm{nM}$ MSP in $1 \mathrm{ml}$ serum-free RPMI medium for $10 \mathrm{~min}$ at $37^{\circ} \mathrm{C}$. Proteins in cell lysates were precipitated with rabbit IgG anti-RON peptide. Samples were separated on an $8.0 \%$ SDS-PAGE, transferred to Immobilon-P membrane, probed with $4 \mathrm{G} 10$, and detected with ECL. RE7 cells were used as a positive control.

phorylation assays in response to human native MSP using selected representative cell lines which express moderate to high levels of RON mRNA versus cell lines lacking detectable RON mRNA. The results are given in Fig. $4 \mathrm{~B}$. The control cell line MDCK-RE7 is included to demonstrate positive phosphorylation of the RON beta chain at $\sim 150 \mathrm{kD}$ (29). The highest level of RON phosphorylation in response to recombinant MSP is observed in H835; somewhat lower levels are present in H187. The same cell lines demonstrate an absence of phosphorylation when MSP treatment was omitted (data not shown). There was no detectable RON phosphorylation in H82 and H720, which lack detectable RON mRNA, indicating that the intensity of RON phosphorylation correlates directly and consistently with RON mRNA levels.

There is no significant effect on proliferation of RON-positive cell lines H835 or H187, or on RON-negative H82 or H720 as determined by viable cell counting and thymidine incorporation after 2-5 d of treatment with MSP (data not shown). However, after 2 wk of treatment of H835 with 3 nM MSP, the viable cell numbers are decreased by $37 \%$, with only $63 \pm 12 \%$ (4 wells total) $\mathrm{H} 835$ as compared to $100 \pm 7 \%$ (5 wells total) viable cells in parallel untreated wells $(P=0.022$, pooled results of two experiments in duplicate or triplicate), as determined by trypan blue exclusion. H187 cell numbers are not altered by 2 wk of similar MSP treatment.

NE cell line adhesion, morphology, and apoptosis. H835 is a well-characterized cell line derived from a human pulmonary carcinoid tumor (35). In cell counting assays, the number of viable $\mathrm{H} 835$ cells adherent to the tissue culture plastic is found to increase significantly in the presence of MSP. However, H835 cells are only partially adherent; most of the viable cells are nonadherent, similar to classic SCLC cell lines (28). The number of total viable cells, including adherent plus nonadherent cells, does not change significantly in the presence of MSP for $5 \mathrm{~d}$. However, there is a consistent, dose-dependent increase in adhesion of H835 cells, which peaks at $\sim 3 \mathrm{nM} \mathrm{MSP}$ (Fig. 5 A).

By phase-contrast microscopy, increased adhesion of H835 is associated with cell flattening, as illustrated by comparing Fig. $5 B$ (untreated cells, showing refractile, rounded clusters of cells) to Fig. $5 C$ (treated with MSP for $6 \mathrm{~d}$, with planar sheets of cells demonstrating decreased ability to refract). To further clarify this morphological change, we carried out scanning EM on H835 cells grown on transwell filters (Fig. 5, $D-F$ ). Untreated H835 grow as cobblestone-like clusters of distinct globoid or golf ball-like cells (Fig. 5 D). After 24 h of treatment with MSP, about half of the cell clusters begin to flatten or spread (Fig. $5 E$ ), and after $6 \mathrm{~d}$ all of the clusters are almost completely flattened (Fig. $5 F$ ). The well-differentiated strongly RON-positive SCLC cell line H187 (which usually only floats) also demonstrates increased cell adhesion to tissue culture plastic in the presence of MSP, but the RON-negative cell line H720 (also a floating cell line) does not adhere when treated with this protein (data not shown).

Trypan blue staining also demonstrates an increase in the proportion of $\mathrm{H} 835$ cells with pyknotic nuclei detected after 5-14 d of culture with MSP, which was comparable to control cultures treated with high doses of the apoptosis-inducing agent, camptothecin (data not shown). Similar morphological evidence of apoptotic nuclei was present on propidium iodide staining (data not shown). Quantitation of the proportion of these small nuclear fragments was carried out using flow cytometric analyses after propidium iodide staining: $3 \mathrm{nM}$ MSP resulted in an increase in the sub- $\mathrm{G}_{1}$ peak from $2 \%$ (in media alone) to $4 \%$ (in MSP) after $5 \mathrm{~d}$, and from 20 to $30 \%$ of the cells after $14 \mathrm{~d}$. These observations suggest that MSP might be increasing the number of cells undergoing programmed cell death. Analysis of genomic DNA on ethidium bromidestained gels revealed a consistent shift towards lower molecular weight species when tumor cells are treated with MSP for 1-5 d (data not shown). A more sensitive and specific assay for apoptosis is fluorescein isothiocyanate-digoxigenin nucleotide labeling of new 3'-OH DNA ends (ApopTag; Oncor, Inc.), which are generated by DNA fragmentation and typically localized in morphologically identifiable nuclei and apoptotic bodies (30). Representative results are given in Fig. 6, in which the ApopTag flow cytometric fluorescence profile of $>1,000$ cells is given on the far left $(y$ axis $=$ relative number of "events" or cells, with scale maximum at 100); DAPI nuclear stain of representative cells is shown in the middle panel, with the corresponding ApopTag fluorescence of the same cells 

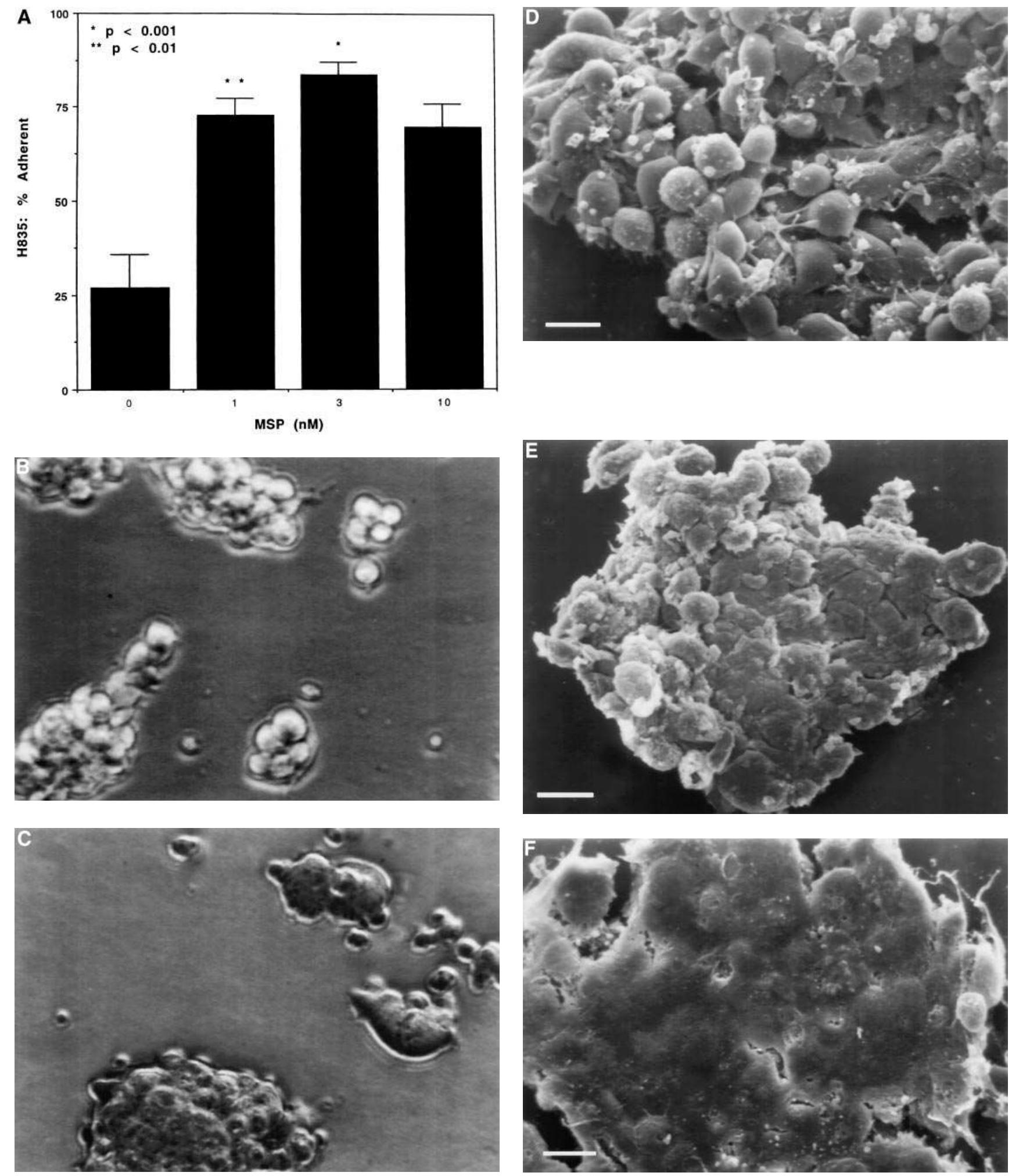

Figure 5. Effect of MSP on NE cell adhesion and morphology. (A) The H835 carcinoid cell line, which grows as partially adherent cell clusters, was cultured without or with MSP $(1-10 \mathrm{nM})$ for $5 \mathrm{~d}$. The numbers of viable adherent and non-adherent cells were counted in triplicate using trypan blue exclusion, and the percentage of total cells which were adherent was calculated. The results shown represent the mean of three separate experiments \pm SEM. $* P<0.001$, $* * P<0.01$. $(B$ and $C)$ Phase-contrast microscopy of H835 cells adherent to tissue culture plastic $(\times 205)$. $(B)$ Untreated H835 grow in loosely adherent clusters which are refractile, three-dimensional, and cobblestone-like in appearance. $(C)$ H835 treated for $5 \mathrm{~d}$ with $3 \mathrm{nM}$ MSP grow as clusters which are more tightly adherent, flatter, and less refractile. $(D-F)$. Scanning EM of H835 cells grown on semipermeable membranes $(\times 512$, bar represents $10 \mu \mathrm{m})$. $(D)$ Untreated $\mathrm{H} 835$ cells grow in three-dimensional clusters which are cobblestone-like in appearance. (E) Clusters of H835 cultured for $1 \mathrm{~d}$ with $3 \mathrm{nM}$ MSP begin to flatten or spread out. (F) Clusters of H835 cultured for $5 \mathrm{~d}$ with $3 \mathrm{nM}$ MSP are almost entirely flattened or two-dimensional in appearance, with indistinct cell-cell boundaries and loss of the cobblestone-like appearance. 

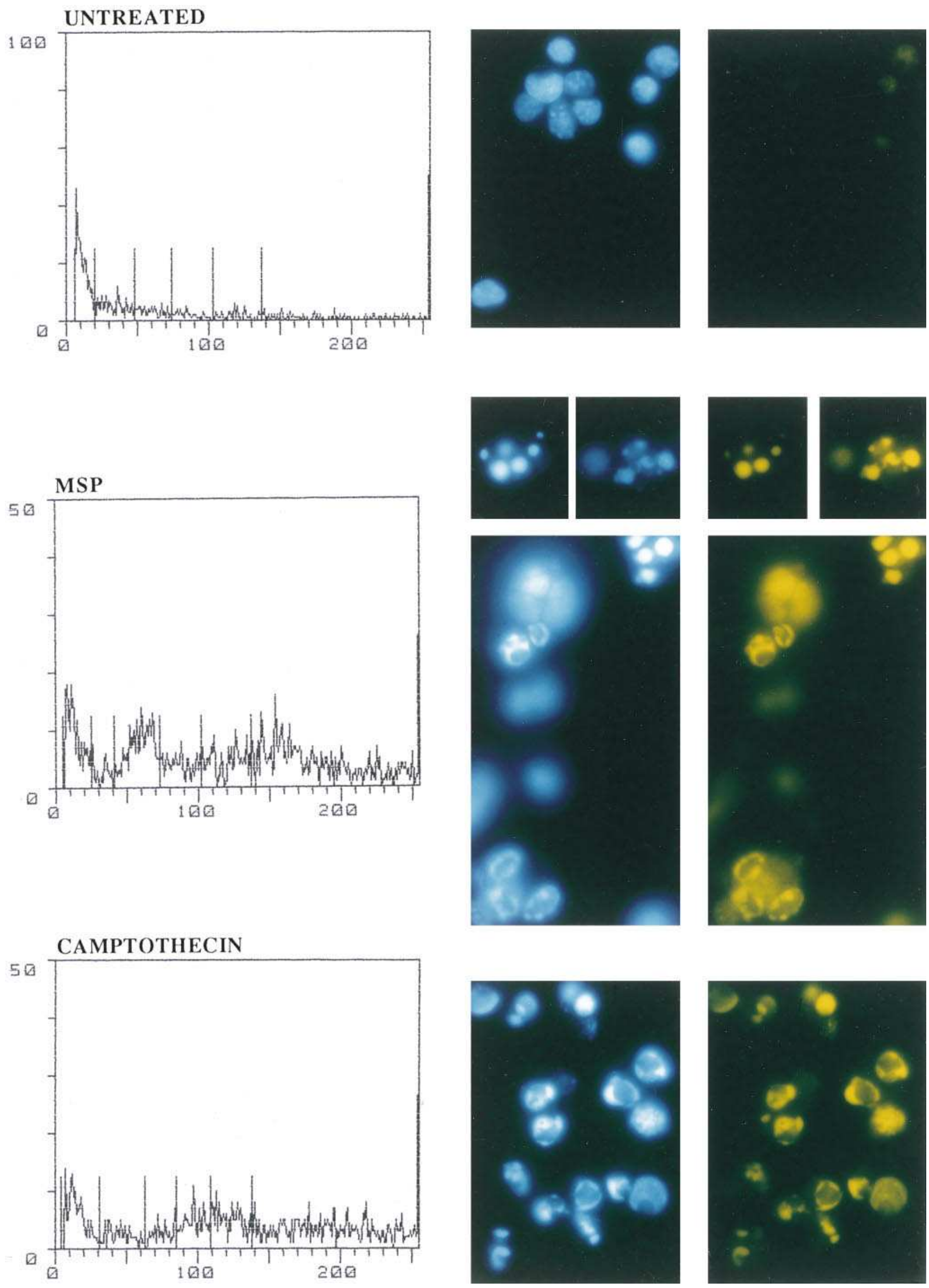
demonstrated on the far right. After $5 \mathrm{~d}$ in culture, untreated H835 cells had low mean fluorescence (Fig. 6, top), which predominantly occurs as homogeneous weak nuclear fluorescence of a fraction of the nuclei. After $5 \mathrm{~d}$ in culture with $3 \mathrm{nM}$ MSP, there was a striking shift, with over half of the cells brightly fluorescing (Fig. 6, middle; note different scale of relative cell numbers with a maximum at 50). The ApopTag fluorescence intensity induced by MSP is variable, being frequently very intense and concentrated in nuclear fragments, or forming peripheral rings of clumped DNA within visible nuclei (Fig. 6, middle, right). As a positive control, H835 cells were treated for $48 \mathrm{~h}$ with high dose camptothecin $(0.01 \%$ final concentration $=100 \mu \mathrm{g} / \mathrm{ml}=287 \mu \mathrm{M}$, a supersaturated solution of camptothecin, a chemotherapeutic agent known to induce apoptosis of tumor cells $\mathrm{IC}_{50} \sim 10-20 \mathrm{nM}$ [36] and normal thymocytes with $K_{50} \sim 1-10 \mu \mathrm{M}$ [37]). Camptothecin treatment of $\mathrm{H} 835$ yielded a fluorescence profile very similar to that of MSP (Fig. 6, bottom, left; note scale same as that shown for MSP), with brightly fluorescent nuclear fragments including peripheral rings of clumped DNA within nuclei and well-formed apoptotic bodies. These results were repeated in five separate experiments with $\mathrm{H} 835$; both the adherent and nonadherent cell populations manifested increased fluorescent labeling together with morphological and flow cytometric evidence of sub- $\mathrm{G}_{1}$ peak/nuclear fragmentation indicating apoptosis. Similar results were also observed with H187, a RON-positive SCLC cell line (three separate experiments; data not shown). The RONnegative $\mathrm{H} 720$ carcinoid cell line did not demonstrate any significant shift in fluorescence with MSP treatment (data not shown).

In situ analyses of apoptosis in nitrosamine-treated hamster lung. To determine whether normal NE cells undergo apoptosis in vivo during the preneoplastic period, preliminary ApopTag analyses were carried out using tissue sections which had been previously immunostained for CGRP to demonstrate hamster pulmonary NE cells $(18,19)$. Photomicrographs of representative sections are given in Fig. 7. Normal adult hamster lung (Fig. 7, $A-C$ ) had easily detectable CGRP-positive $\mathrm{NE}$ cell clusters containing an average of nine nuclei per cluster (Fig. 7, $A$ and $B$ ). Most of the NE cell clusters in lung sections from two normal hamsters were negative for ApopTag fluorescence (Fig. 7 C). Only a few nuclei ( $<5 \%$ of clusters), specifically in the largest NE cell clusters $(>20$ nuclei), had diffusely positive ApopTag fluorescence, but no apoptotic bodies were observed in these normal lungs (data not shown). In contrast, lungs of six hamsters treated with DEN alone (representative photographs given in Fig. 7, $D-I$ ) and lungs of nine hamsters treated with $\mathrm{DEN} / \mathrm{O}_{2}$ (representative photographs given in Fig. 7, $J-L$ ) contained NE cells with nuclear apoptotic bodies which were ApopTag-positive during distinct time periods, as detailed below.

Hamsters treated with DEN alone contained ApopTagpositive pulmonary NE cells with occasional apoptotic bodies as early as $2 \mathrm{wk}$ after the start of DEN, before significant NE cell hyperplasia was present $(18,19)$. After 4 wk of DEN, mild pulmonary NE cell hyperplasia was evident, with about twice as many NE cell clusters per centimeter of airway epithelium (Fig. 7, $D$ and $E$ ) $(18,19)$. There was prominent ApopTag fluorescence in about half of these NE cell clusters after 4 wk (Fig. $7 F$ ), including apoptotic bodies which were easily identifiable in most ApopTag-positive clusters. After 6 wk of DEN (Fig. 7, $G-I$ ) there were fewer CGRP-positive NE cell clusters, and the relative CGRP staining intensity was diminished as compared to the 4-wk time point. In lungs treated with DEN for $6 \mathrm{wk}$, most clusters contained nuclei with morphological evidence of apoptotic bodies on DAPI nuclear staining (Fig. $7 \mathrm{H}$ ) which were positive for ApopTag fluorescence (Fig. $7 \mathrm{I}$ ). After 9 wk of DEN, only rare apoptotic nuclei were evident. After 12 and 16 wk of treatment with DEN alone, apoptotic bodies with ApopTag fluorescence were no longer detectable in lung sections.

Lungs of hamsters treated with $\mathrm{DEN} / \mathrm{O}_{2}$ (Fig. 7, $J-L$ ) were known to develop profound NE cell hyperplasia after 9-12 wk of treatment (Fig. $7 J)(26,27)$, with up to $\sim 10$-fold as many NE cell clusters as compared to untreated controls after $12 \mathrm{wk}$. Only rarely detectable ApopTag-positive nuclear fluorescence occurred in pulmonary NE cells from hamsters treated with $\mathrm{DEN} / \mathrm{O}_{2}$ for $4 \mathrm{wk}$, during the early phase of mild CGRP-positive NE cell hyperplasia. In contrast, all four hamsters treated with $\mathrm{DEN} / \mathrm{O}_{2}$ for 8-9 wk demonstrated NE cell clusters with some morphological evidence of apoptotic bodies on DAPI nuclear staining (Fig. $7 \mathrm{~K}$ ), all of which were positive for ApopTag fluorescence (Fig. $7 \mathrm{~L}$ ); about one-third of these NE cell clusters had prominent apoptotic bodies in over half of the NE cells. After 12 wk of $\mathrm{DEN} / \mathrm{O}_{2}$ treatment, $\mathrm{NE}$ cells in sections from two additional hamsters also contained abundant apoptotic bodies and ApopTag fluorescence. However, after 16 wk of $\mathrm{DEN} / \mathrm{O}_{2}$, ApopTag fluorescence was no longer detectable in lung sections from either of two hamsters, regardless of the size of the NE cell clusters.

\section{Discussion}

The goal of this study was to identify a human chromosome $3 p$ regulatory gene with a hamster homologue induced by nitrosamines during preneoplastic lung. Multiple putative tumor suppressor genes are believed to reside on the short arm of this

Figure 6. Effect of MSP on NE cell apoptosis. H835 cells were grown with or without $3 \mathrm{nM} \mathrm{MSP}$ for 5-14 d. Suspensions of viable cells and pyknotic nuclei were counted using trypan blue exclusion before fixation and fluorescein isothiocyanate-digoxigenin nucleotide labeling of $3{ }^{\prime}-\mathrm{OH}$ DNA ends (ApopTag, Oncor, Inc.). On the left, fluorescence profile of cell populations ( $>1,000$ cells analyzed per group) is given ( $x$ axis, relative cellular fluorescence; $y$ axis, number of cells). Adjacent on the right are photomicrographs $(\times 1,000)$ of representative nuclei stained with DAPI and viewed at 360-370 nm (blue nuclei, central photographs) as a nuclear stain to demonstrate the presence of nuclei; the exact same field viewed at 510-550 nm demonstrates ApopTag fluorescence in a subset of the same cells. Most untreated H835 cells (top) had little or no ApopTag fluorescence, except a few nuclei that were relatively homogeneously fluorescent. In contrast, many MSP-treated H835 cells stain moderately to brightly for ApopTag fluorescence. Most of this fluorescence corresponds to nuclear fragments consistent with multiple apoptotic bodies or single pyknotic nuclei; occasional ring forms are also present, with irregularly clumped chromatin around the nuclear membrane showing bright fluorescence. High dose camptothecin $(287 \mu \mathrm{M}$, bottom) is a positive control for apoptosis (see Methods for details). Note apoptotic bodies and nuclear ring forms in camptothecin-treated cells similar to those observed with MSP treatment. 


\section{NORMAL}

A

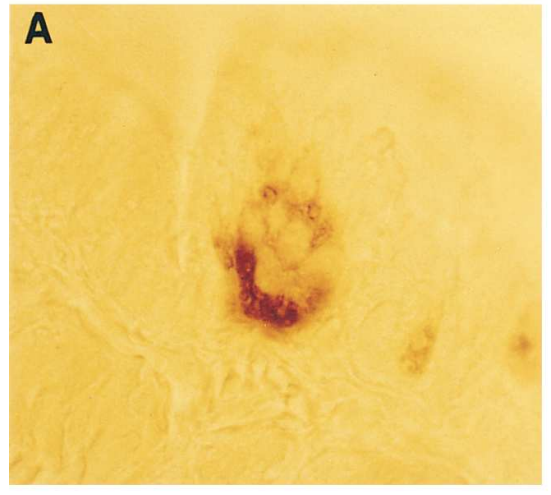

\section{DEN}

D
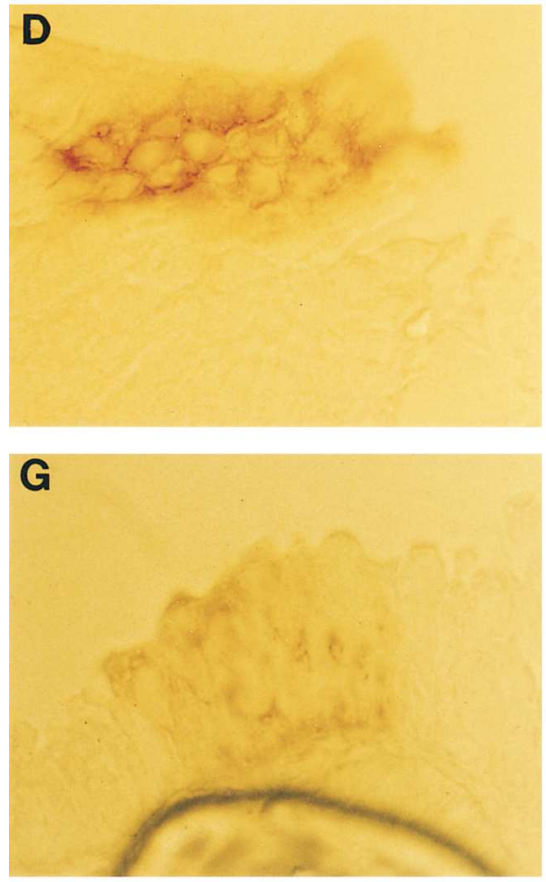

\section{DEN / $0_{2}$}

J

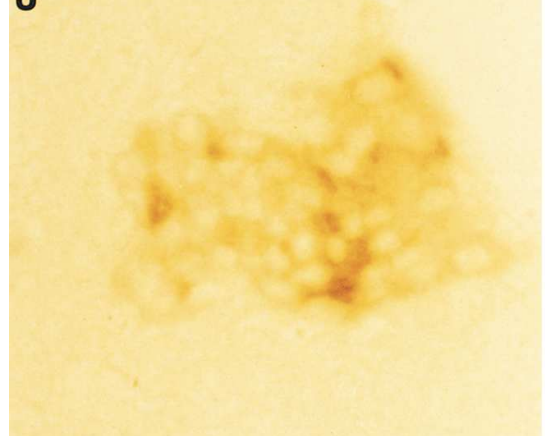

\section{B}
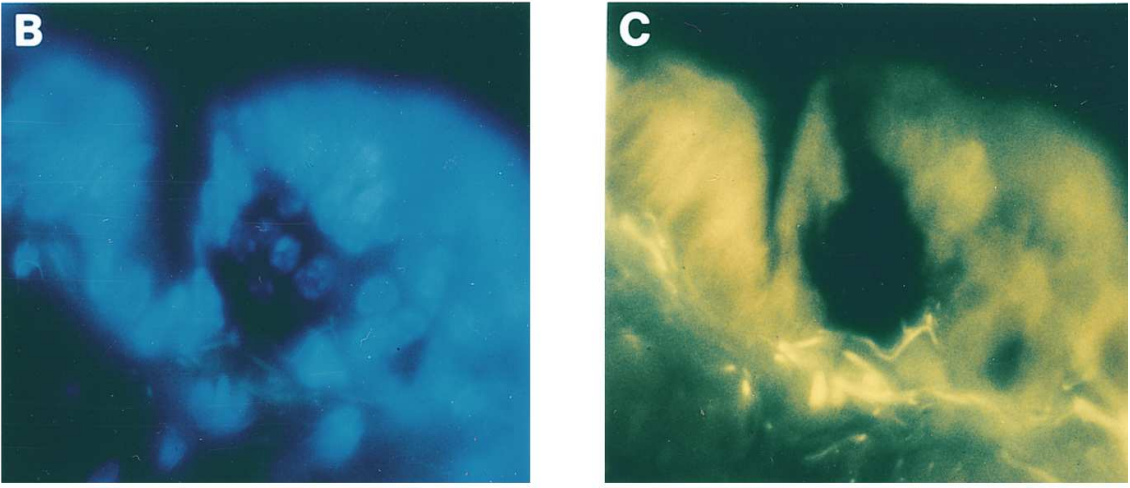

E

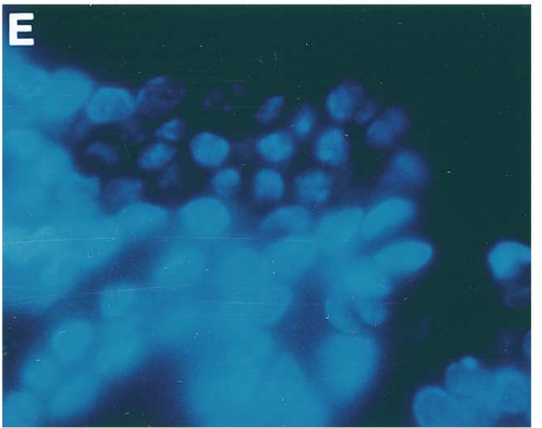

H
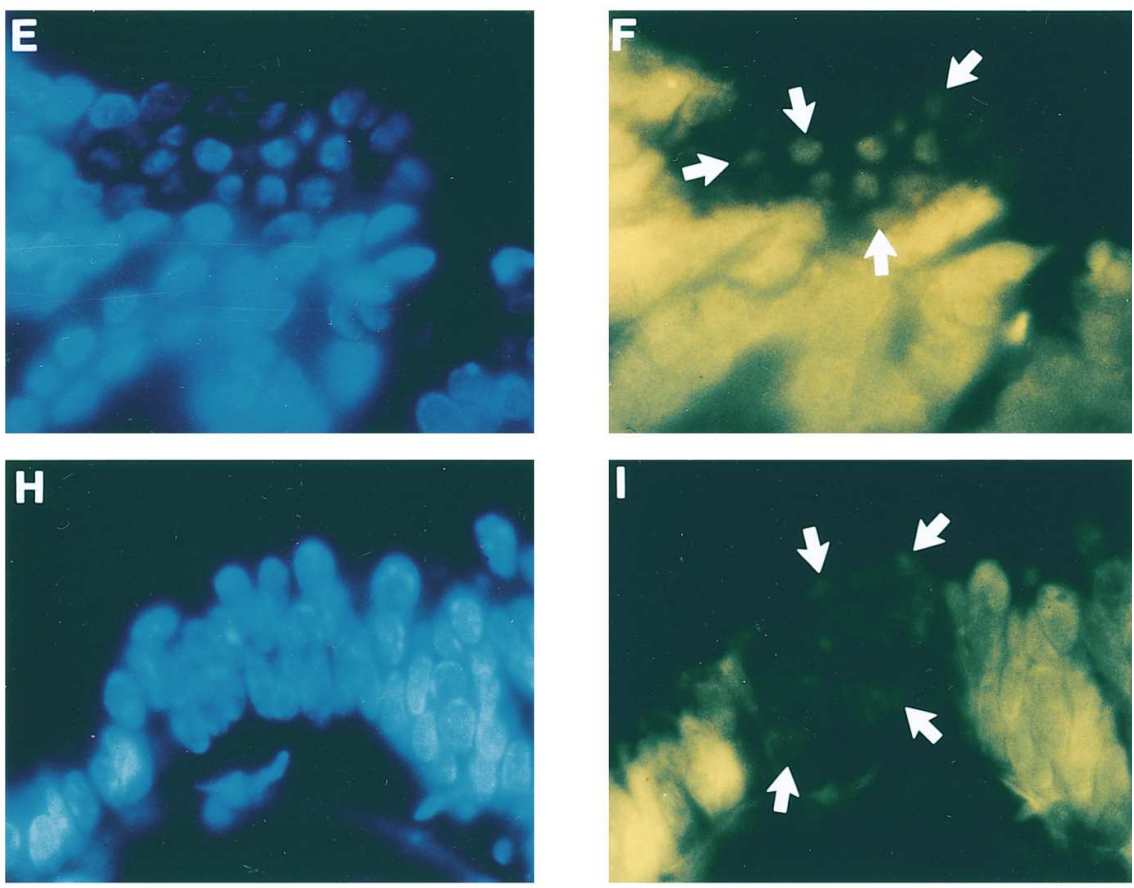

I

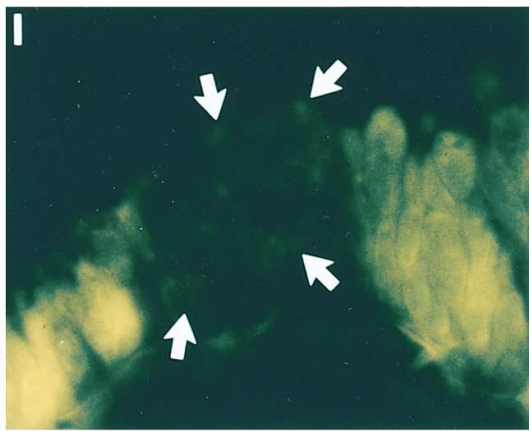

Figure 7. In situ apoptosis of NE cells in hamster lung with and without DEN treatment. ApopTag analyses were carried out using tissue sections which had been previously immunostained for CGRP to demonstrate hamster pulmonary NE cells $(26,27)$. Photomicrographs of representative sections are given as follows $(\times 1,000)$. Left-hand column $(A, D, G, J)$ : Bright field microscopy of tissue section with CGRP immunostaining demonstrating NE cells. Middle column $(B, E, H, K)$ : DAPI fluorescence of the same field demonstrating nuclei. Right-hand column $(C, F, I$, $L)$ : ApopTag fluorescence. $(A, B$, and $C)$ Normal adult hamster lung. Most of the NE cell clusters are negative for ApopTag fluorescence. $(D, E$, 
chromosome, which demonstrates homozygous deletion or loss of heterozygosity in $100 \%$ of SCLCs (38), usually NE in phenotype (16). Because nitrosamine-treated hamsters had spontaneous regression of pulmonary NE cell hyperplasia but developed only non-NE lung tumors, we speculated that these hamsters might activate gene(s) able to downregulate NE cell numbers during preneoplasia and such a gene might have a human homologue on chromosome $3 p$.

The MSP and RON genes both map to human chromosome 3p21.3, which coincides with the shortest region of deletion described in SCLC, according to both loss of heterozygosity (5) and homozygous deletion analyses (39-41). Although we did not observe differences between primary lung tumors and adjacent non-neoplastic lung on genomic Southern blots probed with MSP clone 1697, this type of analysis would not detect point mutations or alterations in other regions of the MSP gene. It is also possible that $3 p$ abnormalities occur early during preneoplasia, such that non-neoplastic epithelial cells adjacent to the primary neoplasm might harbor similar genetic alterations: loss of heterozygosity at the 3p21.3 marker locus for MSP (DNF15S2) has been observed in bronchial epithelial dysplasia as well as neoplasia (42), consistent with the field theory for lung carcinogenesis (43). Alternatively, there could be altered MSP or RON gene expression in the absence of sequence abnormalities in these genes, either as a part of global inactivation of multiple $3 \mathrm{p}$ genes or secondary to aberrant gene expression regulation.

This study suggests that MSP and RON might function to induce apoptosis in pulmonary NE epithelial cells. There are three major pieces of evidence supporting this contention: First, phosphorylation of RON occurs in response to MSP in two NE cell lines which express moderate to high levels of RON mRNA, but not in two cell lines with very low or undetectable RON mRNAs by RT-PCR.

Second, human native MSP induces apoptosis of two different RON-positive NE carcinoma cell lines. This is evidenced by typical morphological changes (nuclear fragmentation and pyknosis), an increased proportion of smaller nuclear fragments verified by flow cytometric analyses, a shift towards fragmented DNA on ethidium gels, and prominent fluorescence with the ApopTag reagent which is comparable to that seen with high doses of camptothecin (44). It should be noted that: $(a)$ the ApopTag fluorescence detection method is considerably more sensitive than detection of DNA ladders; and (b) decreased cell numbers occur subsequent to more cumulative cell death.
Third, MSP and RON are induced in hamster lung during preneoplastic injury by DEN treatment, which coincides with the period of NE cell hyperplasia. (a) Analyses of lung from hamsters given DEN alone show NE cell apoptosis after 2-9 wks of treatment: peak apoptosis at 4-6 wk coincides with the time of earliest detectable NE cell hyperplasia (at 4 wk) and the period of endogenous MSP gene expression (between 2 and $16 \mathrm{wk}$ ). It is possible that decreased NE cell apoptosis after 9 wk of treatment might be due to receptor downregulation in the face of sustained high MSP levels. (b) Analyses of lung from $\mathrm{DEN} / \mathrm{O}_{2}$-treated hamsters demonstrate $\mathrm{NE}$ cell apoptosis in parallel with intense NE cell hyperplasia and MSP gene expression (between 9 and 12 wk), immediately preceding spontaneous regression of NE cell hyperplasia (18). MSP mRNA is expressed in only about half of the hamsters treated with $\mathrm{DEN} / \mathrm{O}_{2}$, which could explain why only half of these animals manifest spontaneous regression. However, lung tissue harvest for analyses of MSP gene expression after 8-12 wk of $\mathrm{DEN} / \mathrm{O}_{2}$-treatment precludes continued follow-up of the same hamsters for the evaluation of spontaneous regression of $\mathrm{NE}$ cell hyperplasia after 16-20 wk of $\mathrm{DEN} / \mathrm{O}_{2}$ treatment.

These effects of MSP on NE cells are not entirely unprecedented. The homologous protein hepatocyte growth factor/ scatter factor has many similar effects on different cell types, including acting as a growth factor for hepatocytes, type II pneumocytes, and other cells (45-47); morphogenesis (48); angiogenesis (49); and cell spreading $(46,50)$. The cellular processes of cell adhesion and spreading are frequently associated $(51,52)$. Although increased cell adhesion can precede apoptosis in carcinoma cell lines, blocking cell adhesion does not alter the course of apoptosis (53), consistent with our observations of apoptosis in both adherent and nonadherent H835 cell populations.

It is of particular interest that we did not detect either MSP or RON mRNAs in any of four cases of primary SCLC, neither in the non-neoplastic lung nor in the primary tumors. We speculate that MSP derived from non-NE cells might function to regulate survival of preneoplastic NE cells in vivo, such that NE cells expressing RON and exposed to MSP during preneoplasia would not survive to become SCLCs. The human lung cancer cell lines producing highest levels of MSP mRNA are derived from adeno- and/or squamous cell carcinomas (Willett, C.G., M.H. Wang, D.I. Smith, V. Shridhar, R. Emanuel, K. Patidar, S.A. Graham, F. Zhang, D.J. Sugarbaker, and M.E. Sunday, manuscript submitted for publication). Although MSP and RON are not expressed significantly in normal ham-

Figure 7 legend (Continued)

and $F$ ) Lung from hamster treated with DEN for 4 wk. Mild pulmonary NE cell hyperplasia is evident, with approximately twice as many NE cell clusters per centimeter of airway epithelium. There is prominent ApopTag fluorescence in about half of the NE cell clusters, including apoptotic bodies which are easily identifiable in most ApopTag-positive clusters. $(G, H$, and $I)$ Lung from hamster treated with DEN for 6 wk. After 6 wk of DEN, there are fewer CGRP-positive NE cell clusters, and the relative CGRP staining intensity is diminished as compared to $4 \mathrm{wk}$. After treatment with DEN for $6 \mathrm{wk}$, most clusters contain nuclei with morphological evidence of apoptotic bodies on DAPI nuclear staining (Fig. $7 \mathrm{H}$ ) which are positive for ApopTag fluorescence, but the fluorescence intensity is diminished compared to 4 wk. $(J, K$, and $L)$ Lung from hamster treated with $\mathrm{DEN} / \mathrm{O}_{2}$ for $8 \mathrm{wk}$. Lungs of hamsters treated with $\mathrm{DEN} / \mathrm{O}_{2}$ are known to develop profound NE cell hyperplasia after 9-12 wk of treatment. This section demonstrates a large NE cell cluster with prominent morphological evidence of apoptotic bodies on DAPI nuclear staining and ApopTag fluorescence.

Note that background cytoplasmic fluorescence of non-NE cells did not obscure the NE cells in these thin $(3 \mu \mathrm{m})$ sections. Also, a negative nuclear image is apparent in most of these non-NE cells. However, we did not evaluate apoptosis in non-NE cells because of the cytoplasmic background fluorescence. Background staining of nerve fibers, connective tissue, and erythrocytes also did not interfere with evaluation of the NE cells. 
ster lung, both genes are induced in early preneoplastic lung injury in hamsters, and could be expressed during lung injury induced by cigarette smoking.

Similarly, spontaneous regression of NE cell hyperplasia in $\mathrm{DEN} / \mathrm{O}_{2}$-treated hamsters could be partly due to MSP production by non-NE epithelial cells acting on RON-positive NE cells, functioning to limit the life span of these cells or their precursors. The early induction of NE cell apoptosis in hamsters treated with DEN alone for 2-4 wk could limit the expansion of NE cells and might explain in part the less intense NE cell hyperplasia observed in animals treated with DEN alone (18). The later onset of both NE cell apoptosis and MSP gene expression in hamsters treated with $\mathrm{DEN} / \mathrm{O}_{2}$ for $8-12 \mathrm{wk}$ is associated with more intense NE cell hyperplasia, suggesting that the absence of NE cell apoptosis might permit greater expansion of the NE cell population. It should also be noted that other factors besides MSP are likely to be implicated in the NE apoptosis response in nitrosamine-treated hamsters: NE cell apoptosis in hamsters treated with DEN alone is less striking than that in animals given $\mathrm{DEN} / \mathrm{O}_{2}$, although MSP mRNA levels are higher and more sustained in hamsters given DEN alone. Part of this apparent discrepancy could be related to receptor downregulation or functional inhibition of signal transduction at high doses of ligand. Alternatively, MSP could interact synergistically with other factors induced by $\mathrm{DEN} / \mathrm{O}_{2}$, which are lacking in animals given DEN alone.

The molecular mechanism of the induction of MSP and/or RON gene expression in nitrosamine-treated hamsters remains to be determined. The induction of DNA damage could be one factor, similar to induction of p53 and Rb by DNA damage (54). However, it is apparent that the addition of other factors, such as hyperoxia, can reverse this trend, arguing for complex mechanisms of gene expression regulation. The genes encoding MSP and its receptor could be upregulated by cytokines during lung injury. The in vivo significance of our in vitro observations remains speculative, but opens new avenues for investigation of tumor phenotypic shifting by selective apoptosis of preneoplastic cell types.

\section{Acknowledgments}

We thank Dr. Ben Neel and Dr. Herbert Oie for providing the lung cancer cell lines and/or RNAs, Dr. Mark Goldberg for the HepG2 cell line, Drs. Cynthia Morton, Andrew Maniotis, and Christopher Chen for helpful discussions, Dr. Tucker Collins and Amy Williams for synthesizing oligonucleotide primers for PCR and sequencing, Dr. John Godleski for assistance with scanning EM, and Dr. David Weinberg and the flow cytometry laboratory at Brigham and Women's Hospital for carrying out cellular analyses. We thank Dr. E.J. Leonard for providing human serum MSP and Dr. Breathnach for rabbit anti-RON IgG.

This work was supported by an American Cancer Society Career Investigator Award (C.G. Willett) and National Institutes of Health grant No. HL-44984 (M.E. Sunday).

\section{References}

1. Minna, J.D., J. Schutte, J. Viallet, F. Thomas, F.J. Kaye, T. Takahashi, M. Nau, J. Whang-Peng, M. Birrer, and A.F. Gazdar. 1990. Transcription factors and recessive oncogenes in the pathogenesis of human lung cancer. Int. J. Cancer. (Suppl. 4):32-34

2. Hinds, P.W., and R.A. Weinberg. 1994. Tumor suppressor genes. Curr. Opin. Genet. Dev. 4:135-141.

3. Collins, V.P., and C.D. James. 1993. Multiple steps in carcinogenesis in- volving alterations of multiple tumor suppressor genes. FASEB (Fed. Am. Soc. Exp. Biol.) J. 7:920-925.

4. Knudson, A.G. 1993. Antioncogenes and human cancer. Proc. Natl. Acad. Sci. USA. 90:10914-10921.

5. Brauch, H., B. Johnson, J. Hovis, T. Yano, A. Gazdar, O.S. Pettengill, S. Graziano, G.D. Sorenson, B.J. Poiesz, J. Minna, et al. 1987. Molecular analysis of the short arm of chromosome 3 in small-cell and non-small-cell carcinoma of the lung. N. Engl. J. Med. 317:1109-1113.

6. Killary, A.M., M.E. Wolf, T.A. Giambernardi, and S.L. Naylor. 1992 Definition of a tumor suppressor locus within human chromosome 3p21-p22. Proc. Natl. Acad. Sci. USA. 89:10877-10881.

7. Miller, Y.M., J.D. Minna, and A.F. Gazdar. 1989. Lack of expression of aminoacylase-1 in small cell lung cancer. J. Clin. Invest. 83:2120-2124.

8. Sithanandam, G., M. Dean, U. Brennscheidt, T. Beck, A. Gazdar, J.D. Minna, H. Brauch, B. Zbar, and U.R. Rapp. 1988. Loss of heterozygosity at the c-raf locus in small cell lung carcinoma. Cancer. 61:1359-1363.

9. LaForgia, S., B. Morse, J. Levy, G. Barnea, L.A. Cannizzaro, F. Li, P.C. Nowell, L. Boghosian-Sell, J. Glick, A. Weston, et al. 1991. Receptor proteintyrosine phosphatase gamma is a candidate tumor suppressor gene at human chromosome region 3p21. Proc. Natl. Acad. Sci. USA. 88:5036-5040.

10. Kok, K., R. Hofstra, A. Pilz, A. van den Berg, P. Terpstra, C.H. Buys, and B. Carritt. 1993. A gene in the chromosomal region 3p21 with greatly reduced expression in lung cancer is similar to the gene for ubiquitin-activating enzyme. Proc. Natl. Acad. Sci. USA. 90:6071-6075.

11. Gebert, J.F., N. Moghal, J.V. Frangioni, D.J. Sugarbaker, and B.G. Neel. 1991. High frequency of retinoic acid receptor beta abnormalities in human lung cancer. Oncogene. 6:1859-1868.

12. Latif, F., K. Tory, J. Gnarra, M. Yao, F.M. Duh, M.L. Orcutt, T. Stackhouse, I. Kuzmin, W. Modi, L. Geil, et al. 1993. Identification of the von Hippel-Lindau disease tumor suppressor gene. Science (Wash. DC). 260:1317-1320.

13. Sozzi, G., M.L. Veronese, M. Negrini, R. Baffa, M.G. Cotticelli, H. Inoue, S. Tornielli, M.A. Pierotti, M. Ohta, K. Huebner, et al. 1996. The FHIT gene at 3p14.2 is abnormal in lung cancer. Cell. 85:17-26.

14. Sekido, Y., S. Bader, F. Latif, J.R. Gnarra, A.F. Gazdar, W.M. Linehan, B. Zbar, M.I. Lerman, and J.D. Minna. 1994. Molecular analysis of the von Hippel-Lindau disease tumor suppressor gene in human lung cancer cell lines. Oncogene. 9:1599-1604.

15. Thiagalingam, S., N.A. Lisitsyn, M. Hamaguchi, M.H. Wigler, J.K.V. Willson, S.D. Markowitz, F.S. Leach, K.W. Kinzler, and B. Vogelstein. 1996. Evaluation of the FHIT gene in colorectal cancers. Cancer Res. 56:2936-2939.

16. Bensch, K.G., B. Corrin, R. Pariente, and H. Spencer. 1968. Oat-cell carcinoma of the lung: its origin and relationship to bronchial carcinoid. Cancer. 22:1163-1172.

17. Bensch, K.G., G.B. Gordon, and L.R. Miller. 1965. Electron microscopic and biochemical studies on the bronchial carcinoid tumor. Cancer. 18: $592-602$.

18. Sunday, M.E., and C.G. Willett. 1992. Induction and spontaneous regression of intense pulmonary neuroendocrine cell differentiation in a model of preneoplastic lung injury. Cancer Res. 52(Suppl.):2677s-2686s.

19. Sunday, M.E., C.G. Willett, K. Patidar, and S.A. Graham. 1994. Modulation of oncogene and tumor suppressor gene expression in a hamster model of chronic lung injury with varying degrees of pulmonary neuroendocrine cell hyperplasia. Lab. Invest. 70:875-888.

20. Sunday, M.E., C.G. Willett, S.A. Graham, V.I.C. Oreffo, R.I. Linnoila, and H. Witschi. 1995. Histochemical characterization of non-neuroendocrine tumors and neuroendocrine cell hyperplasia induced in hamster lung by 4-(methylnitrosamino)-1-(3-pyridyl)-1-butanone with or without hyperoxia. Am. J. Pathol. 147:740-752.

21. Oreffo, V.I.C., H.-W. Lin, R. Padmanbhan, and H. Witschi. 1993. K-ras and p53 point mutations in 4-(methylnitrosamino)-1-(3-pyridyl)-1-butanone induced hamster lung tumors. Carcinogenesis. 14:451-455.

22. Oreffo, V.I.C., H.W. Lin, P.H. Gumerlock, S.A. Kraegel, and H.P. Witschi. 1992. Mutational analysis of a dominant oncogene (c-Ki-ras-2) and a tumor suppressor gene (p53) in hamster lung tumorigenesis. Mol. Carcinog. 6:199-202.

23. Ronsin, C., F. Muscatelli, M.G. Mattei, and R. Breathnach. 1993. A novel putative receptor protein tyrosine kinase of the met family. Oncogene. 8:1195-1202.

24. Smith, D.I., R. Mangrulker, R. Geist, J. Gilbert, K. Kinsman, H. Drabkin, and W. Golembieski. 1989. Saturation of human chromosome 3 with unique sequence hybridization probes. Genomics. 4:453-459.

25. Drabkin, H., M. Wright, M. Jonsen, T. Varkony, C. Jones, M. Sage, S Gold, H. Morse, M. Mendez, and P. Erickson. 1990. Development of a somatic cell hybrid mapping panel and molecular probes for human chromosome 3. Genomics. 8:435-446.

26. Degen, S.J., L.A. Stuart, S. Han, and C.S. Jamison. 1991. Characterization of the mouse cDNA and gene coding for a hepatocyte growth factor-like protein: expression during development. Biochemistry. 30:9781-9791.

27. Yoshimura, T., N. Yuhki, M.H. Wang, A. Skeel, and E.J. Leonard. 1993. Cloning, sequencing, and expression of human macrophage stimulating protein (MSP, MST1) confirms MSP as a member of the family of kringle proteins and locates the MSP gene on chromosome 3. J. Biol. Chem. 268:15461-15468.

28. Carney, D.N., A.F. Gazdar, G. Bepler, J.G. Guccio, P.J. Marangos, 
T.W. Moody, M.H. Zweig, and J.D. Minna. 1985. Establishment and identification of small cell lung cancer cell lines having classic and variant features. Cancer Res. 45:2913-2923.

29. Wang, M.H., C. Ronsin, M.C. Gesnel, L. Coupey, A. Skeel, E.J. Leonard, and R. Breathnach. 1994. Identification of the ron gene product as the receptor for the human macrophage stimulating protein. Science (Wash. DC). 266:117-119.

30. Boudreau, N., C.J. Sympson, Z. Werb, and M.J. Bissell. 1995. Suppression of ICE and apoptosis in mammary epithelial cells by extracellular matrix. Science (Wash. DC). 267:891-893.

31. Han, S., and S.J. Degen. 1993. Genomic organization, chromosomal localization and developmental expression of hepatocyte growth factor-like protein. EXS. 65:81-105.

32. Skeel, A., T. Yashimura, S.D. Showalter, S. Tanaka, E. Appella, and E.J. Leonard. 1991. Macrophage stimulating protein: purification, partial amino acid sequence, and cellular activity. J. Exp. Med. 173:1227-1234.

33. Han, S., L.A. Stuart, and S.J. Degen. 1991. Characterization of the DNF15S2 locus on human chromosome 3: identification of a gene coding for four kringle domains with homology to hepatocyte growth factor. Biochemistry. 30:9768-9780.

34. Bezerra, J.A., D.P. Witte, B.J. Aronow, and S.J. Degen. 1993. Hepatocyte-specific expression of the mouse hepatocyte growth factor-like protein. Hepatology. 18:394-399.

35. Moody, T.W., M. Lee, R.M. Kris, F. Bellot, G. Bepler, H. Oie, and A.F. Gazdar. 1990. Lung carcinoid cell lines have bombesin-like peptides and EGF receptors. J. Cell. Biochem. 43:139-147.

36. Tanizawa, A., A. Fujimori, Y. Fujimori, and Y. Pommier. 1994. Comparison of topoisomerase I inhibition, DNA damage, and cytotoxicity of camptothecin derivatives presently in clinical trials. J. Natl. Cancer Inst. 86:836-842.

37. Onishi, Y., Y. Azuma, Y. Sato, Y. Mizuno, T. Tadakuma, and H. Kizaki. 1993. Topoisomerase inhibitors induce apoptosis in thymocytes. Biochim. Biophys. Acta. 1175:147-154.

38. Whang-Peng, J., C.S. Kao-Shan, E.C. Lee, P.A. Bunn, D.N. Carney, A.F. Gazdar, and J.D. Minna. 1982. Specific chromosome defect associated with human small-cell lung cancer: deletion 3p(14-23). Science (Wash. DC). 215:181-182.

39. Daly, M.C., R.-H. Xiang, D. Buchhagen, C.H. Hensel, D.K. Garcia, A.M. Killary, J.D. Minna, and S.L. Naylor. 1993. A homozygous deletion on chromosome 3 in a small cell lung cancer cell line correlates with a region of tumor suppressor activity. Oncogene. 8:1721-1729.

40. Kok, K., A. van der Berg, M.J.F. Veldhuis, A.Y. van der Veen, M. Franke, E.F.P.M. Schoenmakers, M.M.F. Hulsbeek, A.H. van der Hout, L. de Leij, W. Van de Ven, and C.H.C.M. Buys. 1994. A homozygous deletion in a small cell lung cancer cell line involving a 3p21 region with a marked instability in yeast artificial chromosomes. Cancer Res. 54:4183-4187.

41. Johnson, B.E., A.Y. Sakaguchi, A.F. Gazdar, J.D. Minna, D. Burch, M. Angus, and S.L. Naylor. 1988. Restriction fragment length polymorphism studies show consistent loss of chromosome $3 p$ alleles in small cell lung cancer patients' tumors. J. Clin. Invest. 82:502-507.

42. Chung, G.T.Y, V. Sundaresan, P. Hasleton, R. Rudd, R. Taylor, and P.H. Rabbitts. 1995. Sequential molecular genetic changes in lung cancer development. Oncogene. 11:2591-2598.

43. Lee, J.S., S.M. Lippman, W.K. Hong, J.Y. Ro, S.Y. Kim, R. Lotan, and W.N. Hittelman. 1992. Determination of biomarkers for intermediate end points in chemoprevention trials. Cancer Res. 52(Suppl.):2707s-2710s.

44. Sanderson, M.J., E.R. Dirksen, and P. Satir. 1990. Electron microscopy of respiratory tract cilia. In Electron Microscopy of the Lung. D.E. Schraufnagel, editor. Marcel Dekker, New York. 47-69.

45. Mason, R.J., C.C. Leslie, K. McCormick-Shannon, R.R. Deterding, T. Nakamura, J.S. Rubin, and J.M. Shannon. 1994. Hepatocyte growth factor is a growth factor for rat alveolar type II cells. Am. J. Respir. Cell Mol. Biol. 11:561-567.

46. Gohda, E., S. Nakamura, I. Yamamoto, and J. Minowada. 1995. Hepatocyte growth factor-pleiotropic cytokine produced by human leukemia cells. Leuk. Lymphoma. 19:197-205.

47. Michalopoulos, G.K. 1995. HGF in liver regeneration and tumor promotion. Prog. Clin. Biol. Res. 391:179-185.

48. Bronner-Fraser, M. 1995. Hepatocyte growth factor/scatter factor (HGF/SF) in early development: evidence for a role in neural induction. Trends Genet. 11:423-425.

49. Rosen, E.M., and I.D. Goldberg. 1995. Scatter factor and angiogenesis. Adv. Cancer Res. 67:257-279.

50. Jiang, W.G., D. Lloyds, M.C. Puntis, T. Nakamura, and M.B. Hallett. 1993. Regulation of spreading and growth of colon cancer cells by hepatocyte growth factor. Clin. Exp. Metastasis. 11:235-242.

51. Tawil, N.J., V. Gowri, M. Djoneidi, J. Nip, S. Carbonetto, and P. Brodt. 1996. Integrin alpha3beta1 can promote adhesion and spreading of metastatic breast carcinoma cells on the lymph node stroma. Int. J. Cancer. 66:703-710.

52. Stewart, M.P., C. Cabanas, and N. Hogg. 1996. T cell adhesion to intercellular adhesion molecule-1 (ICAM-1) is controlled by cell spreading and the activation of integrin LFA-1. J. Immunol. 156:1810-1817.

53. Fratelli, M., G. Galli, M. Minto, and G.M. Pasinetti. 1996. Role of clusterin in cell adhesion during early phases of programmed cell death in P19 embryonic carcinoma cells. Biochim. Biophys. Acta. 1311:71-76.

54. Ron, D. 1994. Inducible growth arrest: new mechanistic insights. Proc. Natl. Acad. Sci. USA. 91:1985-1986. 